\author{
Aleksandra Hadzik \\ Najwyższa Izba Kontroli \\ jonik@poczta.onet.pl
}

\title{
Kierunki zmian przepisów dotyczących ubezpieczenia społecznego rolników jako działania zmierzające do poprawy jakości bezpieczeństwa społecznego
}

\author{
Directions of Amendments to the Provisions Applying to the Social \\ Insurance of Farmers as Activity Aimed at the Improvement of the \\ Quality of the Social Safety
}

\section{STRESZCZENIE}

Artykuł dotyczy problematyki zabezpieczenia społecznego rolników, które jest ważnym elementem bezpieczeństwa społecznego. Zabezpieczenie społeczne na odpowiednim poziomie daje gwarancję bezpieczeństwa członkom tej grupy oraz członkom ich rodzin w każdej sytuacji życiowej, a przede wszystkim w tych związanych z brakiem możliwości zarobkowania, chorobą czy innymi przypadkami losowymi. Aby tak się działo, konieczna jest ciągła analiza obowiązujących przepisów i ewentualna ich zmiana, jak również tworzenie nowych rozwiązań zaspokajających potrzeby grupy.

Słowa kluczowe: bezpieczeństwo społeczne; zabezpieczenie społeczne; rolnik

Problematyka bezpieczeństwa jest jedną z podstawowych egzystencjalnych i fundamentalnych wartości i potrzeb każdego człowieka, bez którego nie jest możliwe spokojne i godne życie w realiach XXI w. ${ }^{1}$ Bezpieczeństwo (w tym społeczne)

1 A. Skrabacz, Bezpieczeństwo społeczne. Podstawy teoretyczne i praktyczne, Warszawa 2012, s. 9. W przedmiocie bezpieczeństwa zob. także: A. Hadzik, Straż Graniczna - misja dla bezpieczeństwa, [w:] Rola i zadania instytucji bezpieczeństwa wewnętrznego, red. S. Mazur, M. Ostrowska, M. Zawartka, Katowice 2016, s. 312-313; M. Czuryk, K. Dunaj, M. Karpiuk, K. Prokop, Bezpieczeństwo państwa. Zagadnienia prawne i administracyjne, Olsztyn 2016, s. 17-19; M. Karpiuk, Prawne podstawy bezpieczeństwa, [w:] Podstawowe kategorie bezpieczeństwa narodowego, red. A. Żukowski, M. Hartliński, W.T. Modzelewski, J. Więcławski, Olsztyn 2015, s. 64-70; M. Kar- 
było, jest i będzie najbardziej poszukiwaną wartością, potrzebą i dążeniem ludzi, państw i środowisk międzynarodowych. W realiach XXI w. człowiek stanął przed wyzwaniem tworzenia bezpieczeństwa we wszystkich jego wymiarach i płaszczyznach, począwszy od bezpieczeństwa personalnego i lokalnego, po narodowe i międzynarodowe, a także społeczne, ekologiczne, powszechne, ekonomiczne, publiczne i militarne ${ }^{2}$. We współczesnych czasach szczególnego znaczenia nabiera także problem tworzenia bezpieczeństwa społecznego jako jednej z podstawowych kategorii (dziedziny) bezpieczeństwa narodowego. Jest to bowiem ten rodzaj bezpieczeństwa, którego brak jest szczególnie odczuwany przez ludzi w ich życiu codziennym, prywatnym i zawodowym, narażonym na oddziaływanie różnego rodzaju patologii społecznych.

Różne są definicje bezpieczeństwa społecznego w literaturze przedmiotu. Jedną z pierwszych znanych definicji bezpieczeństwa społecznego jest definicja Międzynarodowej Organizacji Pracy z 1984 r., która pod tym pojęciem rozumie ochronę (zabezpieczenie), jaką społeczeństwo przewiduje dla swoich członków (z wykorzystaniem środków publicznych), którzy znaleźli się w trudnej sytuacji gospodarczej i społecznej, spowodowanej zatrzymaniem lub zmniejszeniem środków finansowych wynikających z choroby, macierzyństwa, wypadku przy pracy, bezrobocia, inwalidztwa, starości i śmierci, a także świadczenie opieki medycznej oraz zapewnienie dotacji dla rodzin z dziećmi³ . M. Leszczyński definiuje bezpieczeństwo społeczne jako całokształt działań prawnych i organizacyjnych realizowanych przez podmioty rządowe (krajowe i międzynarodowe), pozarządowe i samych obywateli, które mają na celu zapewnienie pewnego poziomu życia osobom, rodzinom i grupom społecznym oraz niedopuszczenie do ich marginalizacji i wykluczenia

piuk, K. Prokop, P. Sobczyk, Ograniczenie korzystania z wolności i praw człowieka i obywatela ze względu na bezpieczeństwo państwa i porzadek publiczny, Siedlce 2017, s. 9-21; M. Karpiuk, Bezpieczeństwo jako instytucja konstytucyjna. Zarys problematyki, [w:] Wybrane problemy bezpieczeństwa globalnego po zimnej wojnie, red. W. Gizicki, Lublin 2015, s. 11-19; idem, Zadania i kompetencje zespolonej administracji rządowej w sferze bezpieczeństwa narodowego Rzeczypospolitej Polskiej. Aspekty materialne i formalne, Warszawa 2013, s. 77-89; Aspekty prawne bezpieczeństwa narodowego RP. Część ogólna, red. W. Kitler, M. Czuryk, M. Karpiuk, Warszawa 2013, s. 11-45; M. Karpiuk, Konstytucyjna właściwość Sejmu w zakresie bezpieczeństwa państwa, „Studia Iuridica Lublinensia" 2017, nr 4, DOI: http://dx.doi.org/10.17951/sil.2017.26.4.9, s. 10; idem, Ograniczenie wolności uzewnętrzniania wyznania ze względu na bezpieczeństwo państwa i porządek publiczny, „Przegląd Prawa Wyznaniowego” 2017, t. 9, s. 10-17; idem, Wolność sumienia $i$ wyznania a przestęstwa przeciwko tym wolnościom, [w:] Wolność sumienia i religii a bezpieczeństwo i porzadek publiczny, red. J. Nikołajew, P. Sobczyk, K. Walczuk,Warszawa 2017, s. 49-53; M. Czuryk, Właściwość Rady Ministrów oraz Prezesa Rady Ministrów w zakresie obronności, bezpieczeństwa i porządku publicznego, [w:] System Bezpieczeństwa Narodowego, red. M. Karpiuk, t. 3, Olsztyn 2017, s. 9; M. Bożek, M. Karpiuk, J. Kostrubiec, Zasady ustroju politycznego państwa, Poznań 2012, s. 67-68.

2 A. Skrabacz, Bezpieczeństwo społeczne. Podstawy teoretyczne..., s. 12.

3 Ibidem, s. 33. 
społecznego ${ }^{4}$. Przez J. Gierszewskiego bezpieczeństwo społeczne jest utożsamiane w głównej mierze z państwem i stanowi integralną część bezpieczeństwa państwa ${ }^{5}$. Według M.A. Węgrzyńskiej jest to z kolei ochrona egzystencjalnych podstaw życia ludzi, zapewnienie możliwości zaspokajania indywidualnych potrzeb (materialnych i duchowych) oraz realizacji aspiracji życiowych przez tworzenie warunków do pracy i nauki, ochronę zdrowia oraz gwarancje emerytalne ${ }^{6}$. W. Pokruszyński zwraca uwagę na takie zjawiska, jak asymetryczność, dezorganizacja i nieprofesjonalność rządu, odzwierciedlające stan społecznej nierówności, który nie jest stanem przejściowym, ale istnieje stale, zmieniając jedynie swoje natężenie, zakres i treść ${ }^{7}$. W związku z tym należy mieć na uwadze głównie te procesy, które wymagają profesjonalizmu i sprawnego działania państwa ${ }^{8}$. Także I. Sierpowska odnosi bezpieczeństwo społeczne do funkcjonowania jednostki w państwie, do poczucia wspólnotowości, postępu i równowagi, do harmonizowania interesów osobistych z publicznymi, do jakości życia9. Według A. Skrabacz bezpieczeństwo społeczne to ochrona egzystencjalnych podstaw życia ludzi, zapewnienie możliwości zaspokajania indywidualnych potrzeb (materialnych i duchowych) oraz realizacja aspiracji życiowych przez tworzenie warunków do pracy i nauki, ochronę zdrowia oraz gwarancje emerytalne ${ }^{10}$. Wreszcie istnieje także kolejny pogląd J. Gierszewskiego, w którym za bezpieczeństwo społeczne jest uznawany zbiór przepisów i regulacji normatywno-prawnych mających na celu zapewnienie bezpieczeństwa poprzez wykorzystanie wewnętrznych i zewnętrznych czynników rozwoju społeczno-gospodarczego oraz organizacji i instytucji, które gwarantują niezagrożony rozwój i ład społeczny w kontekście bezpieczeństwa państwa ${ }^{11}$.

${ }^{4}$ M. Leszczyński, Bezpieczeństwo społeczne a sytuacja kryzysowa w gospodarce, „Zeszyty Naukowe Akademii Obrony Narodowej” 2010, nr 2, s. 96.

5 J. Gierszewski, Organizacja systemu bezpieczeństwa społecznego, Warszawa 2013, s. 75.

6 M.A. Węgrzyńska, Identyfikacja bezpieczeństwa ekonomicznego w literaturze i regulacjach prawnych, Wrocław 2015, s. 265.

7 W. Pokruszyński, Bezpieczeństwo. Teoria i praktyka, Józefów 2012, s. 212.

8 Ibidem, s. 212-213.

9 I. Sierpowska, Bezpieczeństwo socjalne jako dobro publiczne, „Zeszyty Naukowe Państwowej Wyższej Szkoły Zawodowej im. Witelona w Legnicy” 2015, nr 3, s. 45.

10 A. Skrabacz, Bezpieczeństwo społeczne, [w:] Bezpieczeństwo narodowe Polski w XXI w., red. R. Jakubczak, J. Flis, Warszawa 2006, s. 413; eadem, Bezpieczeństwo społeczne. Podstawy teoretyczne..., s. 38.

11 J. Gierszewski, Bezpieczeństwo społeczne. Studium z zakresu teorii bezpieczeństwa narodowego, Warszawa 2013, s. 175. W przedmiocie bezpieczeństwa społecznego zob. także: M. Karpiuk, N. Szczęch, Bezpieczeństwo narodowe i międzynarodowe, [w:] System Bezpieczeństwa Narodowego, red. M. Karpiuk, t. 1, Olsztyn 2017, s. 120-124; M. Czuryk, Prawne podstawy bezpieczeństwa narodowego, [w:] Podstawy bezpieczeństwa wspótczesnego państwa (podmiotu). Implikacje, red. J. Pawłowski, Warszawa 2015, s. 559-564; M. Karpiuk, Miejsce samorzadu terytorialnego w przestrzeni bezpieczeństwa narodowego, Warszawa 2014, s. 64-104; Aspekty prawne bezpieczeństwa narodowego RP. Część szczegółowa, red. W. Kitler, M. Czuryk, M. Karpiuk, Warszawa 2013, 
Analiza tych definicji wskazuje, że istotny wkład w tworzenie bezpieczeństwa społecznego spoczywa na aparacie administracji państwowej. Chcąc osiągnąć wysoce akceptowany stan i poziom bezpieczeństwa społecznego, państwo - będąc gwarantem porządku oraz bezpieczeństwa wewnętrznego i zewnętrznego - musi tworzyć warunki niezbędne i konieczne do realizacji zadań z zakresu tej dziedziny bezpieczeństwa narodowego.

Jak wobec tego tworzyć bezpieczeństwo społeczne Polaków wobec wyzwań, jakie niesie za sobą wiek XXI? Co dzisiaj jest gwarantem stabilnego życia, w którym ludzie czują się bezpiecznie, czerpią satysfakcję z wykonywania codziennych obowiązków rodzinnych i zawodowych i nie zaniedbują podstawowych powinności względem siebie, swoich bliskich oraz państwa? ${ }^{12}$

Elementem (częścią) bezpieczeństwa społecznego jest bezsprzecznie zabezpieczenie społeczne. Obejmuje ono kwestie związane z: pomocą społeczną i świadczeniami dla osób oraz gospodarstw domowych znajdujących się w trudnej sytuacji materialnej i społecznej, przeciwdziałaniem patologiom, rządowymi programami w zakresie pomocy społecznej, świadczeń socjalnych, zatrudnienia, rehabilitacji społecznej i zawodowej osób niepełnosprawnych, ale także koordynacją systemów ubezpieczenia społecznego ${ }^{13}$.

Takim systemem jest system ubezpieczenia społecznego rolników. Jest to system odrębny od powszechnego, obejmujący swoim zakresem rolników, ich małżonków i domowników, a także pomocników.

System rolniczy jest repartycyjnym systemem składkowym, uzupełnionym blisko 90-procentową dotacją, dlatego jest określany jako zaopatrzeniowo-składkowy. Charakterystyczne w nim jest to, że jest całkowicie zryczałtowany. Zarówno wysokość emerytur, jak i renty wyznacza kwota najniższej emerytury ZUS. Zryczałtowana jest też składka, tj. 10\% emerytury podstawowej (miesięcznie) i 30\% kwartalnie. Składka podstawowa jest podwyższana dla posiadaczy gospodarstw o powierzchni powyżej 50 ha przeliczeniowych. System obecnie pełni głównie funkcję socjalną, transformacyjną (uzależnienie przyznania emerytury od przekazania gospodarstwa rolnego), wspierającą drobną przedsiębiorczość ${ }^{14}$. Zniesienie tego systemu lub wprowadzenie go do systemu powszechnego może spowodować przeniesienie rolników, z których większość należy do grupy osób o niskich dochodach, do grona osób zmuszonych do korzystania z systemu pomocy społecznej.

\footnotetext{
s. 138-205; M. Karpiuk, Pomoc społeczna jako instytucja umożliwiająca rodzinom przezwyciężanie trudnych sytuacji życiowych i jej miejsce w sferze bezpieczeństwa socjalnego, „,Społeczeństwo i Rodzina" 2017, nr 1, s. 53-54.

12 A. Skrabacz, Bezpieczeństwo..., s. 10-11.

13 Ibidem, s. 171.

${ }^{14}$ W. Jagła, System rolniczy, jaki jest, jaki może być, „Ubezpieczenia w Rolnictwie. Materiały i Studia" 2010, nr 38, s. 97.
} 
Spróbujmy prześledzić na wybranych aspektach, jak przepisy ubezpieczenia społecznego rolników zabezpieczają swoich beneficjentów i jakie jeszcze istnieją w tym zakresie możliwości.

Kwestie ubezpieczenia społecznego rolników reguluje ustawa z dnia 20 grudnia 1990 r. o ubezpieczeniu społecznym rolników ${ }^{15}$. W jaki sposób i jakie grupy osób zabezpiecza ustawa? Umożliwia ona objęcie ubezpieczeniem społecznym rolników (art. 1) rolników i pracujących z nimi domowników, którzy:

1) posiadają obywatelstwo polskie lub

2) przebywają na terytorium Rzeczypospolitej Polskiej na podstawie wizy, zezwolenia na pobyt czasowy, zezwolenia na pobyt stały, zezwolenia na pobyt rezydenta długoterminowego Unii Europejskiej, zgody na pobyt ze względów humanitarnych, zgody na pobyt tolerowany lub w związku z uzyskaniem w Rzeczypospolitej Polskiej statusu uchodźcy lub ochrony uzupełniającej, lub

3) są obywatelami państw członkowskich Unii Europejskiej, Konfederacji Szwajcarskiej lub państw członkowskich Europejskiego Porozumienia o Wolnym Handlu (EFTA) - stron umowy o Europejskim Obszarze Gospodarczym (chyba że przepisy Unii Europejskiej stanowią inaczej).

Po pierwsze, ubezpieczenie obejmuje obywateli, o których mowa w ust. 1 pkt 3 , jeżeli przepisy Unii Europejskiej dotyczące stosowania systemów zabezpieczenia społecznego nie stanowią inaczej.

Po drugie, w ubezpieczeniu wyodrębnia się:

1) ubezpieczenie wypadkowe, chorobowe i macierzyńskie,

2) ubezpieczenie emerytalno-rentowe.

Rolnikiem jest pełnoletnia osoba fizyczna, zamieszkująca i prowadząca na terytorium Rzeczypospolitej Polskiej, osobiście i na własny rachunek, działalność rolniczą $\mathrm{w}$ pozostającym $\mathrm{w}$ jej posiadaniu gospodarstwie rolnym, w tym również $\mathrm{w}$ ramach grupy producentów rolnych, a także osoba, która przeznaczyła grunty prowadzonego przez siebie gospodarstwa rolnego do zalesienia. Przepisy dotyczące rolnika stosuje się także do małżonka rolnika, jeżeli pracuje on w gospodarstwie rolnika lub w gospodarstwie domowym bezpośrednio związanym z gospodarstwem rolnym.

Domownikiem rolnika jest osoba bliska rolnikowi, która pozostaje z rolnikiem we wspólnym gospodarstwie domowym lub zamieszkuje na terenie jego gospodarstwa rolnego albo w bliskim sąsiedztwie, a ponadto stale pracuje $\mathrm{w}$ tym gospodarstwie rolnym i nie jest związana z rolnikiem stosunkiem pracy.

Obowiązkowo (z mocy ustawy) podlegają ubezpieczeniu:

1) rolnik, którego gospodarstwo obejmuje obszar użytków rolnych powyżej

1 ha przeliczeniowego lub dział specjalny,

2) domownik tego rolnika.

15 T.j. Dz.U. z 2017 r., poz. 2336 ze zm. 
- jeżeli ten rolnik lub domownik nie podlega innemu ubezpieczeniu społecznemu lub nie ma ustalonego prawa do emerytury lub renty albo nie ma ustalonego prawa do świadczeń z ubezpieczeń społecznych.

W przypadku prowadzenia gospodarstwa rolnego o powierzchni poniżej 1 ha przeliczeniowego istnieje możliwość objęcia ubezpieczeniem dobrowolnym (tzw. na wniosek). Trzeba tu jednak mieć na uwadze, że nieopłacenie składki w terminie powoduje wyłączenie z tego ubezpieczenia, a sama dobrowolność często powoduje, że osoby nie wykorzystują możliwości uzyskania ubezpieczenia.

Przepisy ustawy (obowiązujące od 2 maja $2004 \mathrm{rr}^{16}$ ) umożliwiają rolnikowi i domownikowi, prowadzącym (pracującym) w gospodarstwie powyżej 1 ha przeliczeniowego, prowadzenie pozarolniczej działalności gospodarczej. Dzięki temu osoby te nie są automatycznie przenoszone do powszechnego systemu ubezpieczenia (ZUS). Są tutaj jednak do spełnienia pewne warunki:

1) przed rozpoczęciem prowadzenia pozarolniczej działalności gospodarczej należy podlegać ubezpieczeniu nieprzerwanie przez co najmniej 3 lata,

2) po rozpoczęciu prowadzenia pozarolniczej działalności gospodarczej lub rozpoczęciu współpracy przy prowadzeniu tej działalności należy:

- złożyć w Kasie oświadczenie o kontynuowaniu tego ubezpieczenia w terminie 14 dni od dnia rozpoczęcia wykonywania pozarolniczej działalności gospodarczej lub współpracy przy tej działalności,

- jednocześnie nadal trzeba prowadzić działalność rolniczą lub stale pracować w gospodarstwie rolnym, obejmującym obszar użytków rolnych powyżej 1 ha przeliczeniowego, lub w dziale specjalnym,

- nie być pracownikiem i nie pozostawać w stosunku służbowym,

- nie mieć ustalonego prawa do emerytury lub renty albo do świadczeń $\mathrm{z}$ ubezpieczeń społecznych,

- kwota należnego podatku dochodowego za poprzedni rok podatkowy od przychodów z pozarolniczej działalności gospodarczej nie może przekraczać kwoty ogłaszanej przez ministra właściwego do spraw rozwoju wsi w drodze obwieszczenia w Dzienniku Urzędowym Rzeczypospolitej Polskiej „Monitor Polski”.

Zaświadczenie albo oświadczenie, że nie została przekroczona kwota podatku dochodowego, rolnik lub domownik prowadzący pozarolniczą działalność gospodarczą, podlegający ubezpieczeniu, obowiązany jest także złożyć w Kasie do dnia 31 maja każdego roku podatkowego. Niezachowanie terminu złożenia oświadczenia jest równoznaczne z ustaniem ubezpieczenia od dnia rozpoczęcia wykonywania pozarolniczej działalności gospodarczej lub współpracy przy prowadzeniu tej działalności. 
Kolejną kwestią zmierzającą do utrzymania ciągłości ubezpieczenia społecznego rolników było wprowadzenie zmian do ustawy od 1 stycznia 2015 r. ${ }^{17}$, które umożliwiły dalsze podleganie ubezpieczeniu społecznemu rolników przy jednoczesnym wykonywaniu umowy, o której mowa w art. 6 ust. 1 pkt 4 ustawy z dnia 13 października 1998 r. o systemie ubezpieczeń społecznych (umowa zlecenia) lub powołania do rady nadzorczej. Osoba wykonująca takie czynności podlega nadal ubezpieczeniu społecznemu rolników pomimo objęcia jej z tego tytułu innym ubezpieczeniem społecznym, jeżeli przychód osiągany z tego tytułu w rozliczeniu miesięcznym nie przekracza kwoty równej minimalnemu wynagrodzeniu za pracę, ustalonemu na podstawie odrębnych przepisów.

Ta możliwość przenikania się systemów ubezpieczenia daje jednostkom gwarancję stabilności ubezpieczenia i możliwość łączenia okresów ubezpieczenia opłaconych w systemie powszechnym $\mathrm{z}$ tymi uregulowanymi w systemie rolniczym. Ma to znaczenie zwłaszcza w kontekście ustawy o emeryturach kapitałowych, która zaczęła obowiązywać w 2009 r. ${ }^{18}$, a która była bardzo krytykowana w momencie wejścia w życie właśnie ze względu na fakt, iż wiele osób na jej podstawie straciło możliwość otrzymania świadczenia emerytalnego. Ustawa ta bowiem uniemożliwiła osobom urodzonym po 31 grudnia 1948 r. doliczanie do okresów podlegania ubezpieczeniu społecznemu rolników okresów podlegania w systemie powszechnym, przez co wielu ludzi straciło możliwość przejścia na emeryturę w okresie, w którym uzyskaliby prawo do świadczenia, ale w okresie liczonym przez sumowanie okresów podlegania w ZUS i KRUS.

Istotne dla bezpieczeństwa systemu społecznego są także zmiany obowiązujące od 1 października $2015 \mathrm{r}^{19}$, powodujące niewyłączanie z ubezpieczenia społecznego rolników osób, które opiekują się niepełnosprawnym członkiem rodziny, i chociaż $z$ tego tytułu zaprzestały prowadzenia gospodarstwa rolnego, mogą nadal podlegać ubezpieczeniu społecznemu rolników.

Co jeszcze można poprawić w obowiązujących przepisach, aby określonym podmiotom zapewnić jeszcze większe poczucie bezpieczeństwa?

Przede wszystkim należy zastanowić się nad wspomnianymi wyżej zmianami wprowadzonymi przez ustawę o emeryturach kapitałowych. Zasadne byłoby jednak łączenie okresów opłacania składek w systemie powszechnym i w systemie rolniczym, a tym samym umożliwienie spełnienia warunków do otrzymania świadczenia po zsumowaniu okresów podlegania w obu systemach.

Obecnie wdraża się w życie także przepisy dotyczące nowej kategorii osób ubezpieczonych, co jest też ważnym krokiem do objęcia ochroną ubezpieczeniową innych osób niż rolnik i domownik (szerszego grona osób). Mianowicie od

\footnotetext{
${ }^{17}$ Dz.U. z 2014 r., poz. 1831.

${ }^{18}$ Dz.U. z 2008 r., nr 228, poz. 1507.

19 Dz.U. z 2015 r., poz. 1506.
} 
18 maja 2018 r. obowiązuje zmiana wprowadzająca nowe pojęcie ubezpieczonego - pomocnika rolnika. Jest to osoba pełnoletnia, z którą rolnik zawarł umowę o pomocy przy zbiorach. Pomoc ta polega na wykonywaniu konkretnych czynności wymienionych w ustawie. Oprócz umożliwienia tą zmianą objęcia ubezpieczeniem szerszego grona osób, można założyć, że zmiana ta spowoduje ograniczenie tzw. szarej strefy w rolnictwie, zwłaszcza że pomocnikiem może być nie tylko obywatel polski, ale także cudzoziemiec.

W sferze rozważań pozostaje możliwość objęcia ubezpieczeniem społecznym rolników kobiet, które w ramach tzw. pomocy sąsiedzkiej świadczą pomoc przy opiece nad dziećmi, a które przed urodzeniem dziecka nie pracowały w gospodarstwie rolnym męża i z tego powodu nie były objęte ubezpieczeniem społecznym rolników. Wykonując pracę związaną z opieką nad dziećmi, powinny mieć możliwość objęcia ubezpieczeniem społecznym.

Należałoby również zastanowić się nad przemodelowaniem definicji rolnika, która stwarza pewną dowolność. Sam fakt osobistego prowadzenia działalności rolniczej nie jest bowiem możliwy do sprawdzenia przez organy Kasy. Generalnie do ubezpieczenia dochodzi po oświadczeniu osoby, że prowadzi działalności rolniczą na posiadanych gruntach i trudne jest zweryfikowanie takiego oświadczenia. Może zatem należałoby zastanowić się nad koniecznością objęcia ubezpieczeniem każdej osoby, która posiada gospodarstwo rolne, a nie podlega ubezpieczeniu w systemie powszechnym.

Kwestią do ponownego rozważenia pozostaje, moim zdaniem, także dobrowolne ubezpieczenie rolników. Czy ten sposób podlegania zapewnia bezpieczeństwo podmiotom objętym tego rodzaju ubezpieczeniem? Czy może należałoby wprowadzić obowiązkowe ubezpieczenie dla każdej osoby, która prowadzi działalność rolniczą, bez względu na to, jaka jest powierzchnia użytkowanego gospodarstwa? Należy mieć na uwadze, że w Polsce istnieje około 1804 tys. gospodarstw rolnych o powierzchni powyżej 1 ha użytków rolnych, prowadzonych przez osoby fizyczne, w tym składki na ubezpieczenie społeczne rolników opłaca około 1157 tys. ich użytkowników. Około 185 tys. osób posiada działki orne o powierzchni nieprzekraczającej 1 ha użytków rolnych - osoby te są ubezpieczone na wniosek (dobrowolnie). Przyjmując uproszczony rachunek, że powierzchnia gruntów w hektarach przeliczeniowych jest zazwyczaj bliska powierzchni wyrażonej w hektarach fizycznych (MRiRW 2008), szacuje się, że w Polsce funkcjonuje aktualnie ponad 830 tys. indywidualnych gospodarstw rolnych o powierzchni 1 ha użytków rolnych, których użytkownicy nie ubezpieczają w KRUS ani siebie, ani członków swych rodzin. Oznacza to, że istnieje znaczna liczba gospodarstw rolnych, których właściciele i ich domownicy czerpią większość swych dochodów z pracy zarobkowej poza gospodarstwem i dlatego są zobowiązani do opłacania składek w ZUS ${ }^{20}$. Może to jednak też oznaczać, że część

${ }^{20}$ M. Zieliński, Sytuacja ekonomiczna gospodarstw rolnych osób nieobjętych ubezpieczeniem społecznym rolników, „Ubezpieczenia w Rolnictwie. Materiały i Studia” 2008, nr 33, s. 32-33. 
osób, które powinny podlegać ubezpieczeniu społecznemu rolników, nie jest objęta tym systemem, a tym samym nie podlegają one żadnemu ubezpieczeniu społecznemu.

Problemem niesygnalizowanym wyżej, bardziej natury proceduralnej, jest możliwość wstecznego wyłączania rolników (małżonków, domowników) z ubezpieczenia społecznego rolników. Sytuacja taka ma miejsce, gdy rolnik podlegający ubezpieczeniu rolniczemu jednocześnie np. pracuje, ale fakt ten zgłasza Kasie po upływie dłuższego czasu zatrudnienia. Ustawa o ubezpieczeniu społecznym rolników wskazuje tu na odpowiednie stosowanie przepisów ustawy o systemie ubezpieczeń społecznych ${ }^{21}$, a ta w każdym czasie pozwala na weryfikację okresów ubezpieczenia i tym samym na wyłączenie z ubezpieczenia w okresie wstecznym. Sytuacja taka może mieć negatywne dla zainteresowanego konsekwencje, np. w postaci braku prawa do świadczenia, braku możliwości zwrotu opłaconej składki ze względu na przedawnienie, braku możliwości kontynuowania ubezpieczenia społecznego rolników przy jednoczesnym prowadzeniu działalności gospodarczej.

Podsumowując, można stwierdzić, że ustawa zabezpiecza szerokie grono osób, ponieważ przez wprowadzane zmiany bezpieczeństwo obejmuje coraz więcej ludzi. Istnieją jednak jeszcze obszary, które wymagają analizy i aktualizacji, dotyczy to zwłaszcza możliwości uzupełniania się przez dwa systemy ubezpieczeniowe: system powszechny i system ubezpieczenia społecznego rolników. Należy przy tym pamiętać, że rolnictwo to dział gospodarki narodowej dostarczający najważniejszy produkt potrzebny człowiekowi, jakim jest żywność. W strategię bezpieczeństwa narodowego wpisuje się zapewnienie bezpieczeństwa żywnościowego. Gospodarstwa domowe rolników charakteryzują się relatywnie niskim, na tle pozostałych grup społeczno-ekonomicznych, poziomem bezpieczeństwa ekonomicznego. Ponad połowa z nich żyje bowiem poniżej koszyka minimum socjalnego zapewniającego godziwy poziom życia. Dlatego bezpieczne funkcjonowanie rolnictwa jest uzależnione od sprawnie funkcjonującego systemu ubezpieczenia społecznego rolników i ubezpieczeń gospodarczych.

\section{BIBLIOGRAFIA}

Aspekty prawne bezpieczeństwa narodowego RP. Część ogólna, red. W. Kitler, M. Czuryk, M. Karpiuk, Warszawa 2013.

Aspekty prawne bezpieczeństwa narodowego RP. Część szczegółowa, red. W. Kitler, M. Czuryk, M. Karpiuk, Warszawa 2013.

Bożek M., Karpiuk M., Kostrubiec J., Zasady ustroju politycznego państwa, Poznań 2012.

Czuryk M., Prawne podstawy bezpieczeństwa narodowego, [w:] Podstawy bezpieczeństwa wspótczesnego państwa (podmiotu). Implikacje, red. J. Pawłowski, Warszawa 2015.

${ }^{21}$ T.j. Dz.U. z 2017 r., poz. 1778. 
Czuryk M., Właściwość Rady Ministrów oraz Prezesa Rady Ministrów w zakresie obronności, bezpieczeństwa i porządku publicznego, [w:] System Bezpieczeństwa Narodowego, red. M. Karpiuk, t. 3, Olsztyn 2017.

Czuryk M., Dunaj K., Karpiuk M., Prokop K., Bezpieczeństwo państwa. Zagadnienia prawne i administracyjne, Olsztyn 2016.

Gierszewski J., Bezpieczeństwo społeczne. Studium z zakresu teorii bezpieczeństwa narodowego, Warszawa 2013.

Gierszewski J., Organizacja systemu bezpieczeństwa społecznego, Warszawa 2013.

Hadzik A., Straż Graniczna - misja dla bezpieczeństwa, [w:] Rola i zadania instytucji bezpieczeństwa wewnętrznego, red. S. Mazur, M. Ostrowska, M. Zawartka, Katowice 2016.

Jagła W., System rolniczy, jaki jest, jaki może być, „Ubezpieczenia w Rolnictwie. Materiały i Studia” 2010, $\mathrm{nr} 38$.

Karpiuk M., Bezpieczeństwo jako instytucja konstytucyjna. Zarys problematyki, [w:] Wybrane problemy bezpieczeństwa globalnego po zimnej wojnie, red. W. Gizicki, Lublin 2015.

Karpiuk M., Konstytucyjna właściwość Sejmu w zakresie bezpieczeństwa państwa, „Studia Iuridica Lublinensia" 2017, nr 4, DOI: http://dx.doi.org/10.17951/sil.2017.26.4.9.

Karpiuk M., Miejsce samorzadu terytorialnego w przestrzeni bezpieczeństwa narodowego, Warszawa 2014.

Karpiuk M., Ograniczenie wolności uzewnętrzniania wyznania ze względu na bezpieczeństwo państwa i porzadek publiczny, „Przegląd Prawa Wyznaniowego” 2017, t. 9.

Karpiuk M., Pomoc społeczna jako instytucja umożliwiająca rodzinom przezwyciężanie trudnych sytuacji życiowych i jej miejsce w sferze bezpieczeństwa socjalnego, „Społeczeństwo i Rodzina” 2017, nr 1.

Karpiuk M., Prawne podstawy bezpieczeństwa, [w:] Podstawowe kategorie bezpieczeństwa narodowego, red. A. Żukowski, M. Hartliński, W.T. Modzelewski, J. Więcławski, Olsztyn 2015.

Karpiuk M., Wolność sumienia i wyznania a przestępstwa przeciwko tym wolnościom, [w:] Wolność sumienia i religii a bezpieczeństwo i porzadek publiczny, red. J. Nikołajew, P. Sobczyk, K. Walczuk, Warszawa 2017.

Karpiuk M., Zadania i kompetencje zespolonej administracji rządowej w sferze bezpieczeństwa narodowego Rzeczypospolitej Polskiej. Aspekty materialne i formalne, Warszawa 2013.

Karpiuk M., Prokop K., Sobczyk P., Ograniczenie korzystania z wolności i praw człowieka i obywatela ze względu na bezpieczeństwo państwa i porządek publiczny, Siedlce 2017.

Karpiuk M., Szczęch N., Bezpieczeństwo narodowe i międzynarodowe, [w:] System Bezpieczeństwa Narodowego, red. M. Karpiuk, t. 1, Olsztyn 2017.

Leszczyński M., Bezpieczeństwo społeczne a sytuacja kryzysowa w gospodarce, „Zeszyty Naukowe Akademii Obrony Narodowej” 2010, nr 2.

Pokruszyński W., Bezpieczeństwo. Teoria i praktyka, Józefów 2012.

Sierpowska I., Bezpieczeństwo socjalne jako dobro publiczne, „Zeszyty Naukowe Państwowej Wyższej Szkoły Zawodowej im. Witelona w Legnicy” 2015, nr 3.

Skrabacz A., Bezpieczeństwo społeczne, [w:] Bezpieczeństwo narodowe Polski w XXI w., red. R. Jakubczak, J. Flis, Warszawa 2006.

Skrabacz A., Bezpieczeństwo społeczne. Podstawy teoretyczne i praktyczne, Warszawa 2012.

Węgrzyńska M.A., Identyfikacja bezpieczeństwa ekonomicznego w literaturze i regulacjach prawnych, Wrocław 2015.

Zieliński M., Sytuacja ekonomiczna gospodarstw rolnych osób nieobjętych ubezpieczeniem społecznym rolników, „Ubezpieczenia w Rolnictwie. Materiały i Studia” 2008, nr 33. 
Pobrane z czasopisma Studenckie Zeszyty Naukowe http://szn.umcs.pl

Data: 26/04/2023 14:49:53

Kierunki zmian przepisów dotyczących ubezpieczenia społecznego rolników...

\section{SUMMARY}

The article concerns issues of the social security for farmers which is an important component of the social safety. The appropriate level of the social security guarantees it to the members of this group as well as for their families in each life situation but most of all associated with the lack of possibility of working, illness or other unexpected circumstances. In order to manage it, constant analysis of the obligatory regulations is necessary or even change in these regulations and creating new solutions which will meet the needs of the group.

Keywords: social safety; social security; farmer 